University of Nebraska - Lincoln

DigitalCommons@University of Nebraska - Lincoln

Publications from USDA-ARS / UNL Faculty

U.S. Department of Agriculture: Agricultural

Research Service, Lincoln, Nebraska

September 1985

\title{
Carbon Dioxide Exchange Rate of Tall Fescue-Leaf Area vs. Leaf Weight Basis
}

Wallace Wilhelm

University of Nebraska-Lincoln, wwilhelm1@unl.edu

C. J. Nelson

USDA-ARS

Follow this and additional works at: https://digitalcommons.unl.edu/usdaarsfacpub

Part of the Agricultural Science Commons

Wilhelm, Wallace and Nelson, C. J., "Carbon Dioxide Exchange Rate of Tall Fescue-Leaf Area vs. Leaf Weight Basis" (1985). Publications from USDA-ARS / UNL Faculty. 103.

https://digitalcommons.unl.edu/usdaarsfacpub/103

This Article is brought to you for free and open access by the U.S. Department of Agriculture: Agricultural Research Service, Lincoln, Nebraska at DigitalCommons@University of Nebraska - Lincoln. It has been accepted for inclusion in Publications from USDA-ARS / UNL Faculty by an authorized administrator of DigitalCommons@University of Nebraska - Lincoln. 


\title{
Carbon Dioxide Exchange Rate of Tall Fescue- Leaf Area vs. Leaf Weight Basis ${ }^{1}$
}

\author{
W. W. Wilhelm and C. J. Nelson²
}

\begin{abstract}
The basis used for expression of carbon dioxide exchange rate (CER) of single leaves may alter the relative ranking of genotypes being selected for a breeding program. Therefore, field and growth chamber experiments were conducted on 16 genotypes of tall fescue (Festuca arundinacea Schreb.) to determine the relative merit of expressing CER data on a leaf area or leaf weight basis. Genotypes were grown in plots in the field and in pots in the growth chamber. The CER was measured using an infrared gas analyzer. Herbage yield was determined. Significant genotypic variation within experiments was found for CER when expressed on either a leaf area or leaf weight basis. The correlation coefficient between CER on a leaf area and leaf weight basis ranged from 0.82 to 0.94 for the field experiments and was 0.76 for the growth chamber experiment. Comparision of coefficients of variation (CV's) associated with the two methods of expressing CER indicated slightly higher variation in data based on leaf weight. The CV's for the field experiments were between 11.5 and $16.5 \%$, suggesting that either method of expression of CER for tall fescue could be satisfactorily used to detect genotypic differences. Leaf area is suggested as the preferred base because of its association with radiation interception. Further, genetic control of CER per unit leaf area appears to be independent from specific leaf weight.
\end{abstract}

Additional index words: Festuca arundinacea Schreb., Yield, Genetic variation, Specific leaf weight, Photosynthesis.

$\mathbf{R}$ EPORTS of significant positive relationships between specific leaf weight (SLW, $\mathrm{g} \mathrm{m}^{-2}$ ) and leaf photosynthesis (Pearce et al., 1969; Wilson and Cooper, 1969; Topark-Ngarm et al., 1977) have intensified interest in evaluating the influence of method of expression of leaf photosynthetic rates. This is especially true in determining differences between genotypes and assessing photosynthesis relationship to yield. Ogren (1976) suggested that variation in leaf thickness or density (SLW) may account for much of the genetic variation reported in leaf photosynthetic rates of soybean [Glycine $\max$ (L.) Merr.]. With forages, where leaf tissue is the major component of

\footnotetext{
${ }^{1}$ Contribution from the Missouri Agric. Exp.Stn. Journal Series no. 9555. Received 3 Aug. 1984.

${ }^{2}$ Formerly graduate assistant (now plant physiologist, USDAARS, Univ. of Nebraska-Lincoln, NE 68583) and professor of agronomy, Dep. of Agronomy, Univ. of Missouri, Columbia, MO 65201 .
}

yield, the area or weight basis for expressing photosynthesis may be of prime importance.

Sufficient genetic variation in photosynthesis was available and heritability great enough in tall fescue (Festuca arundinacea Schreb.) to facilitate progress by recurrent selection (Asay et al., 1974). Earlier, we (Wilhelm and Nelson, 1978a, 1978b) compared four genotypes of tall fescue selected for high and low $\mathrm{CO}_{2}$ exchange rate (CER) on a leaf area basis in combination with high and low yield and found that CER ranking remained consistent over a range of radiation densities, leaf ages, and times of day. Further, the rate of canopy development was more critical in determining forage yield than was CER of single leaves (Nelson et al., 1977).

Purposes of this study were to evaluate the influence of method of expressing leaf CER (leaf area or leaf weight basis) on variation among genotypes, the relationship between leaf CER and yield, and the relationship between SLW and leaf CER of tall fescue.

\section{MATERIALS AND METHODS \\ Field Study}

Sixteen genotypes of tall fescue representing a broad genetic background were selected based on earlier work (Nelson et al., 1975), with four representing each category of high leaf CER-high forage yield ( $\mathrm{H}-\mathrm{H})$, high CER-low yield (H-L), low CER-high yield (L-H), and low CER-low yield (L-L). Previous CER classification was on a leaf area basis. Plants were propagated vegetatively during September 1973 into 0.5 by $1.5 \mathrm{~m}$ field plots. Plots were replicated four times on a Mexico silt loam soil (fine montmorillonitic, mesic Udollic Ochraqualfs) at the Agronomy Research Center near Columbia, MO. Plots consisted originally of 33 plants of a given genotype placed in three rows $0.25 \mathrm{~m}$ apart with plants $0.15 \mathrm{~m}$ apart within rows. Borders between plots $(0.85 \mathrm{~m})$ were seeded in rows with 'Kentucky 31 ' tall fescue. Plots were fertilized with 26,12 , and $22 \mathrm{~kg} \mathrm{ha}^{-1}$ of elemental $\mathrm{N}, \mathrm{P}$, and $\mathrm{K}$, respectively, at time of establishment. Similar quantities were also applied once early in spring 1974 and following each harvest during the tenure of the experiment. Plots were irrigated with $50 \mathrm{~mm}$ of water on 3 July, 27 July, and 8 Aug. 1975. 
Carbon dioxide exchange rates were measured on all experimental units on 25 June and 21 Sept. 1974 and 27 May and 30 July 1975, using the air-sealed leaf chamber infrared gas analysis system described by Nelson et al. (1974). Six leaf blades with recently formed collars were measured simultaneously in each plot when canopies were 0.20 to $0.30 \mathrm{~m}$ high. Measurements were made on clear days with photosynthetic photon flux density (PPFD) greater than $1500 \mu \mathrm{mol} \mathrm{m}^{-2} \mathrm{~s}^{-1}$ (LiCor LI-190S Quantum Sensor ${ }^{3}$ ) within $3 \mathrm{~h}$ of $1200 \mathrm{~h}$. Environments were such that soil moisture was adequate, stomatal resistance was $<500 \mathrm{~s} \mathrm{~m}^{-1}$, air temperature was within the optimum range (Treharne and Nelson, 1975), and $\mathrm{CO}_{2}$ concentration was about $0.66 \mathrm{~g}$ $\mathrm{m}^{-3}$. Following CER measurements, area of the blade segment inserted into the leaf chamber was calculated from length and midwidth measurements. Leaf blade tissue used for the measurement was dried at $70^{\circ} \mathrm{C}$ for $48 \mathrm{~h}$ and weighed. Carbon dioxide exchange rates were calculated on both a leaf area and leaf weight basis. Specific leaf weights were calculated.

Forage yields were determined by cutting forage to an average height of $80 \mathrm{~mm}$ on $6 \mathrm{May}, 7 \mathrm{July}, 15 \mathrm{Aug}$., and 27 Sept. 1974 and 13 May, 18 June, 12 Aug., and 10 Nov. 1975 with a flail harvester similar to that described by Buker (1967). Subsamples were oven-dried and then used to calculate yield on a dry weight basis.

\section{Growth Chamber Study}

Three vegetatively propagated plants of each of the 16 genotypes used in the field study were planted into 100 $\mathrm{mm}$ diam by $150-\mathrm{mm}$ deep plastic pots with drain holes. Pots had been filled with a soil mix of two parts Mexico silt loam topsoil, one part sand, and one part peat moss. Plants were maintained in a greenhouse for 2 months to become established. When the plants averaged 20 tillers per pot, they were transferred to controlled environment chambers with a 14-h photoperiod of $500 \mu \mathrm{mol} \mathrm{m} \mathrm{m}^{-2} \mathrm{~s}^{-1}$ PPFD provided by cool-white fluorescent and incandescent bulbs. Temperature was $23 / 16^{\circ} \mathrm{C}$ (light/dark), and relative humidity was maintained at $>\mathbf{5 0 \%}$. Distilled water was added as needed to maintain plants in a well-watered condition. Once each week, $50 \mathrm{~mL}^{-1}$ pot $^{-1}$ of a complete nutrient solution (Epstein, 1972) was added. Pots were arranged in a randomized, complete block design with four replications.

After a 2-week acclimatization period, plants were cut to $60 \mathrm{~mm}$ above soil level and allowed to regrow. The earliest leaves to appear in the vegetative regrowth showed cut ends, indicating they had formed partially before cutting. When fully expanded but previously uncut leaves had appeared in all pots, CER was measured as described above, except the system was modified to measure two leaves per pot simultaneously. Leaf blade area and weight were determined as in the field study; CER was expressed on both a leaf area and leaf weight basis; and SLW was calculated. Four weeks after the initial harvest, yield was determined by clipping the plants $60 \mathrm{~mm}$ above soil level, drying the material at $70^{\circ} \mathrm{C}$ for $48 \mathrm{~h}$, and weighing.

A series of 16 separate, controlled environment experiments was conducted on four of the 16 genotypes used in the previous studies.

One genotype was selected from each of the CER-yield categories (Wilhelm and Nelson, 1978a, 1978b). In each

\footnotetext{
${ }^{3}$ Mention of a trademark, proprietary product, or vendor does not constitute a guarantee or warranty of the product by the USDA or the University of Missouri and does not imply its approval to the exclusion of other products or vendors that may be suitable.
}

Table 1. Mean $\mathrm{CO}_{2}$ exchange rate on a leaf area (CER ) and leaf weight $\left(\mathrm{CER}_{W}\right.$ ) basis and specific leaf weight (SLW) of 16 tall fescue genotypes measured in the field during 1974 and 1976 and the growth chamber during 1974. Range among genotypes is given in parentheses.

\begin{tabular}{lccc}
\hline Date & CER $_{\mathrm{A}}$ & CER $_{\mathrm{W}}$ & $\mathrm{SLW}$ \\
\hline & $\mu \mathrm{mol} \mathrm{m}^{-2} \mathrm{~g}^{-1}$ & $\mu \mathrm{mol} \mathrm{kg}^{-1} \mathrm{~g}^{-1}$ & $\mathbf{g ~ m}^{-1}$ \\
Field, 1974 & & & \\
25 June & 8.5 & 168 & 51.6 \\
& $(5.4-14.5)$ & $(85-318)$ & $(41.7-76.0)$ \\
21 Sept. & 12.1 & 300 & 40.7 \\
& $(7.6-16.4)$ & $(173-381)$ & $(32.2-48.6)$ \\
Field, 1975 & & & \\
27 May & 19.5 & 424 & 46.5 \\
30 July & $(9.2-32.4)$ & $(169-690)$ & $(35.6-59.0)$ \\
& 11.9 & 222 & 54.5 \\
Growth chamber & $(5.2-17.6)$ & $(77-364)$ & $(37.1-75.7)$ \\
& 11.2 & 271 & 42.0 \\
& $(6.3-15.5)$ & $(132-423)$ & $(28.6-59.8)$ \\
\hline
\end{tabular}

experiment, three ramets were planted into $100-\mathrm{mm}$ diam by $150-\mathrm{mm}$ deep plastic pots and were grown in controlled environment chambers. Three experiments were conducted at $21 / 16^{\circ} \mathrm{C}$ and 14 -h photoperiod, 12 at $23 / 18^{\circ} \mathrm{C}$ and 12-h photoperiod, and one at $25 / 20^{\circ} \mathrm{C}$ and $15-\mathrm{h}$ photoperiod. In all experiments, relative humidity was $>$ $50 \%$, and PPFD from cool-white fluorescent tubes and incandescent bulbs was $500 \mu \mathrm{mol} \mathrm{m}^{-2} \mathrm{~s}^{-1}$. In each of these studies, CER, SLW, and yield were measured as above.

\section{RESULTS AND DISCUSSION}

Dates of measurements were significantly different for CER on a leaf area basis $\left(\mathrm{CER}_{\mathrm{A}}\right)$, CER on a leaf weight basis $\left(C E R_{W}\right)$, and SLW in the field study (Table 1). The highest CER was found during May 1975 when mean air temperature for the week prior to measurement and at the time of measurements was near optimum $\left(23^{\circ} \mathrm{C}\right)$ for tall fescue (Treharne and Nelson, 1975), and $30 \mathrm{~mm}$ of rainfall had occurred within the previous week, and regrowth was 14 days old. The CER $\mathrm{W}_{\mathrm{W}}$ showed trends (among dates) similar to $C_{E R}$ even though there were differences in SLW among growth environments. Environmental conditions at each measurement date were different; however, genetic differences in CER were always significant (Table 1).

Correlation coefficients between CER measured at different dates in the field (Table 2) indicated that all relationships were positive but not always significant. Lack of significance emphasizes the fact that previous history and present environment may alter the relative CER. This supports Nelson and Asay (1974), who reported that evaluation of genotypes must be made several times throughout the season to select genotypes with particular CER characteristics over a wide range of environmental conditions. In contrast, short-term environmental changes, such as PPFD, as well as leaf aging for up to 6 weeks did not show genotypic interactions in CER in tall fescue specifically selected for stability in CER (Wilhelm and Nelson, 1978a, 1978b). Woledge and Jewiss (1969) and Woledge (1973) reported the environment in which a leaf develops has long-term effects on CER of perennial grasses. Apparently, the effect of the canopy environment was not offset by expressing CER on a weight basis compared with an area basis (Table 
Table 2. Correlation coefficients between environments for CER of 16 tall fescue genotypes expressed on a leaf area and leaf weight basis. Numbers of observations are given in parentheses.

\begin{tabular}{|c|c|c|c|c|}
\hline Date & $\begin{array}{c}21 \text { Sept. } \\
1974\end{array}$ & $\begin{array}{c}27 \text { May } \\
1975\end{array}$ & $\begin{array}{l}\text { 30 July } \\
1975\end{array}$ & $\begin{array}{l}\text { Growth } \\
\text { chamber }\end{array}$ \\
\hline \multicolumn{5}{|c|}{ Leaf area basis } \\
\hline $\begin{array}{l}25 \text { June } 1974 \\
21 \text { Sept. } 1974 \\
27 \text { May } 1975 \\
30 \text { July } 1975\end{array}$ & $\begin{array}{c}0.11 \\
(48)\end{array}$ & $\begin{array}{c}0.26^{*} \\
(64) \\
0.04 \\
(48)\end{array}$ & $\begin{array}{c}0.21 \\
(64) \\
0.18 \\
(48) \\
0.35^{* *} \\
(64)\end{array}$ & $\begin{array}{c}0.23 \\
(64) \\
0.21 \\
(48) \\
-0.08 \\
(64) \\
0.15 \\
(64)\end{array}$ \\
\hline \multicolumn{5}{|c|}{ Leaf weight basis } \\
\hline $\begin{array}{l}25 \text { June } 1974 \\
21 \text { Sept. } 1974 \\
27 \text { May } 1975 \\
\text { 30 July } 1975\end{array}$ & $\begin{array}{l}0.29 * \\
(48)\end{array}$ & $\begin{array}{c}0.28^{*} \\
(64) \\
0.12 \\
(48)\end{array}$ & $\begin{array}{c}0.36^{* *} \\
(64) \\
0.25 \\
(48) \\
0.36^{* *} \\
(64)\end{array}$ & $\begin{array}{r}0.14 \\
(64) \\
0.27 \\
(48) \\
-0.01 \\
(64) \\
-0.13 \\
(64)\end{array}$ \\
\hline
\end{tabular}

*** Signfiicant at $p<0.05$ and $p<0.01$, respectively.

2). In addition, it should be noted that no significant relationship was found between CER measured in field and growth chamber environments.

Correlation coefficients between $\mathrm{CER}_{\mathrm{A}}$ and $\mathrm{CER}_{\mathrm{W}}$ in tall fescue ranged from 0.81 to 0.94 for the field study and were 0.76 for the growth chamber study (Table 3). This was in contrast to data on soybean reported by Dornhoff and Shibles (1970) and recalculated by Ogren (1976), which indicated no relationship $(p>0.05)$ between rates of CER $\mathrm{A}_{\mathrm{A}}$ and CER $\mathrm{w}_{\mathrm{w}}$. Data on tall fescue indicated that CER by both methods of expression varied similarly over the 2-yr course of the experiment.

Specific leaf weight was related negatively to $C E R_{W}$, but no relationship occurred on an area basis (Table 3). Similarly, in the growth chamber, no relationship was found between $\mathrm{CER}_{\mathrm{A}}$ and SLW, whereas a negative relationship was found between $C E R_{W}$ and SLW. In tall fescue, variation in leaf thickness or density was not associated with variation in CER $_{\mathrm{A}}$. Positive correlations between SLW and CER $R_{A}$ have been found with soybean (Beuerlein and Pendleton, 1971; Dornhoff and Shibles, 1970), oats (Avena sativa L.) (Criswell and Shibles, 1971), alfalfa (Medicago sativa $\mathbf{L}$.) (Pearce et al., 1969), and perennial ryegrass (Lolium perenne L.), (Wilson and Cooper, 1969). Lack of correlation has been found with peanuts (Arachis hypogaea L.) (Pallas and Samish, 1974), wheat (Triticum astivum L.) (Dunestone et al., 1973), and maize (Zea mays L.) (Crosbie et al., 1977). Apparently, factors such as species and environment influenced the type of relationship found in each study. Correlations between yield and either CER $_{A}$ or CER $_{W}$ in our studies were generally positive (Table 3 ) but not significant.

Four genotypes, which best fit their respective $\mathrm{CER}_{\mathrm{A}}$-yield categories, were studied in 16 separate growth chamber experiments over a 2 -yr period. Genotypes consistently exhibited significantly different CER on both a leaf area and leaf weight basis (Table 4). Mean CER over the 16 experiments ranged from 6.2 to $9.5 \mu \mathrm{mol} \mathrm{CO} \mathrm{Cm}^{-2} \mathrm{~s}^{-1}$ and 146 to 191
Table 3. Correlation coefficients between $\mathrm{CO}_{2}$ exchange rates expressed on a leaf-area $\left(\mathrm{CER}_{A}\right)$ and leaf-weight $\left(\mathrm{CER}_{\mathrm{w}}\right)$ basis, specific leaf weight (SLW), and forage yield. Data are for 16 genotypes of tall fescue. Numbers of observations are given for each date in parentheses.

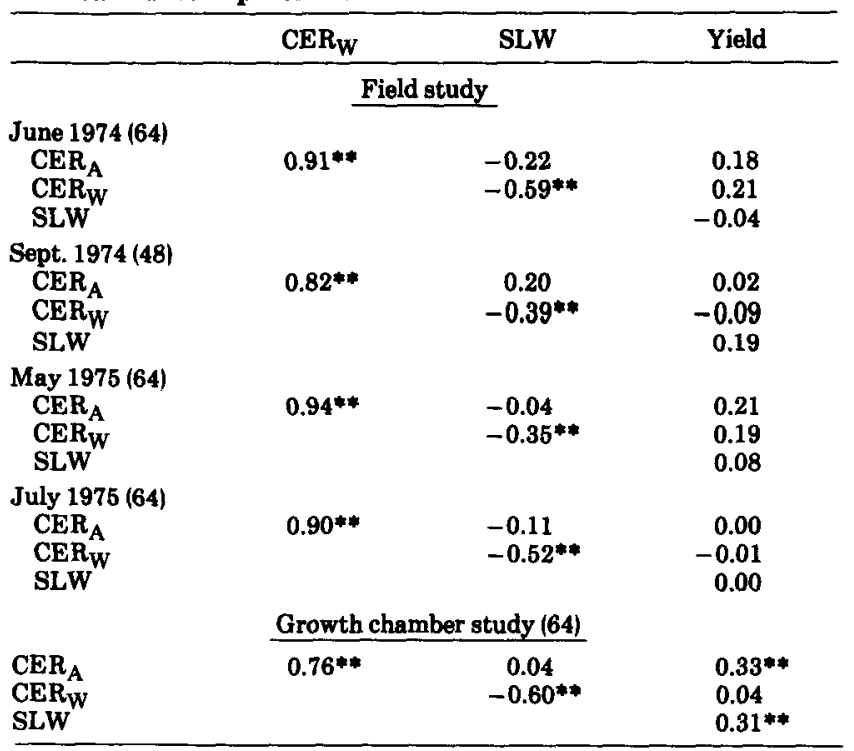

** Significant at $p<0.01$.

Table 4. Mean $\mathrm{CO}_{2}$ exchange rate on a leaf area $\left(\mathrm{CER}_{\mathrm{A}}\right)$ and leaf weight $\left(C E R_{W}\right)$ basis and specific leaf weight (SLW) of tall fescue. Data represent 16 separate experiments utilizing genotypes selected for specific CER $_{\text {A-yield relationships. Each }}$ number is the mean of 64 observations.

\begin{tabular}{cccc}
\hline Genotype & CER $_{\mathrm{A}}$ & CER $_{\mathrm{W}}$ & $\mathrm{SLW}$ \\
\hline CER $_{\mathrm{A}}$-yield & $\mu \mathrm{mol} \mathrm{m}^{-2}^{-1}$ & $\mu \mathrm{mol} \mathrm{kg}^{-1} \mathrm{~s}^{-1}$ & $\mathrm{~g} \mathrm{~m}^{-2}$ \\
H-H & 10.3 & 192 & 56.0 \\
H-L & 9.6 & 206 & 46.5 \\
L-H & 6.6 & 139 & 47.2 \\
L-L & 7.1 & 160 & 45.3 \\
LSD $_{0.08}$ & 1.4 & 27 & 7.4 \\
\hline
\end{tabular}

$\mu \mathrm{mol} \mathrm{CO} \mathrm{kg}^{-1} \mathrm{~s}^{-1}$. The genotype-by-experiment interactions for both $\mathrm{CER}_{\mathrm{A}}$ and $\mathrm{CER}_{\mathrm{W}}$ were not significant.

Correlation coefficients between $\mathrm{CER}_{\mathrm{A}}$ and $\mathrm{CER}_{\mathrm{W}}$ over the four genotypes and 16 experiments were $0.78^{* *}$, which closely compared with earlier growth chamber data (Table 3). Correlation coefficients between CER $_{\mathrm{A}}$ and SLW were $0.51 * *$, but SLW and $\mathrm{CER}_{\mathrm{W}}$ were not correlated significantly. The high SLW value (Table 4) of the $\mathrm{H}-\mathrm{H}$ genotype probably led to the significant correlation coefficient because SLW for the other three genotypes was similar. Carbon dioxide exchange rates among the remaining three genotypes were independent of SLW as indicated by $\mathrm{CER}_{\mathrm{A}}$ and $\mathrm{CER}_{\mathrm{W}}$ both showing significant differences $(p<0.05)$.

Coefficients of variation ranged from 11 to $15 \%$ for $\mathrm{CER}_{\mathrm{A}}$ and from 12 to $16 \%$ for $\mathrm{CER}_{\mathrm{W}}$ across experiments, indicating similar genotypic separation could be achieved with either type of expression. However, within an experiment, the CER $\mathrm{w}_{\mathrm{w}}$ generally had about a 1 percentage unit higher $C V$ than did the $\operatorname{CER}_{\mathrm{A}}$. This probably was because $\mathrm{CER}_{\mathrm{A}}$ was measured on a specific length of leaf tissue $(100 \mathrm{~mm})$, which, together with leaf width, defined the leaf area. The $\mathrm{CER}_{\mathrm{W}}$ was determined by removing the specific 
length of leaf tissue from the plant and drying and weighing it. These additional processes and associated errors of cutting, drying, and weighing probably added other sources of variation, which may account for the higher $\mathrm{CV}$ associated with $\mathrm{CER}_{\mathrm{w}}$.

Leaf blade area in tall fescue is a more meaningful basis of expression for CER than is leaf blade weight since area also represents the light-intercepting surface. This conclusion would be consistent with that of Sestak et al. (1971), who concluded that leaf dry weight was not a logical basis for CER since it has little or no direct relationship with radiation absorption. This latter factor was especially critical for improving species such as tall fescue, where rates of leaf elongation (Horst et al., 1978) were related positively, but rates of single leaf photosynthesis (Nelson et al., 1975) were not associated with genotypic differences in forage yield. Following four cycles of recurrent selection for leaf area expansion rate (LAER) of individual leaves, those populations having a twofold higher LAER (Nelson and Sleper, 1983), and probably higher SLW (Zarrough et al., 1983), had a field-measured CER $\mathrm{A}_{\mathrm{A}}$ that was similar to that of populations selected for slow LAER (Nelson and Sleper, 1983). In a subsequent growth chamber study (Zarrough et al., 1984), populations selected for rapid LAER had significantly higher mean SLW but a similar CER $_{\text {A }}$ compared with populations selected for slow LAER, 51 vs $37 \mathrm{~g} \mathrm{~m}^{-2}$ and 14.1 vs $13.9 \mu \mathrm{mol}$ $\mathrm{CO}_{2} \mathrm{~m}^{-2} \mathrm{~s}^{-1}$, respectively. The variation in the relationship among SLW, LAER, and CER reported between dicotyledons (Ogren, 1976; Pearce et al., 1969) and Gramineae may be a result of differences in meristem location and morphological development. The above results indirectly showed that genetic differences in CER of tall fescue tended to be independent from SLW. Nevertheless, SLW as an independent factor appears to be a critical yield determinant of forage grasses (Topark-Ngarm et al., 1977; Zarrough et al., 1984).

\section{REFERENCES}

Asay, K.H., C.J. Nelson, and G.L. Horst. 1974. Genetic variability for net photosynthesis in tall fescue. Crop Sci. 14:571-574.

Beurlein, J.E., and J.W. Pendleton. 1971. Photosynthetic rates and light saturation curves of individual soybean leaves under field conditions. Crop Sci. 11:217-219.

Buker, R.J. 1967. Forage plot harvester. Agron. J. 59:203-204.

Criswell, J.G., and R.M. Shibles. 1971. Physiological basis for genotypic variation in net photosynthesis of oat leaves. Crop Sci. 11:550-553

Crosbie, T.M., J.J. Mock, and R.B. Pearce. 1977. Variability and selection advance for photosynthesis in Iowa Stiff Stalk Synthetic maize population. Crop Sci. 17:511-514.
Dornhoff, G.M., and R.M. Shibles. 1970. Varietal differences in net photosynthesis of soybean leaves. Crop Sci. 10:42-45.

Dunestone, R.L., R.M. Gifford, and L.T. Evans. 1973. Photosynthetic characteristics of modern and primitive wheat species in relation to ontogeny and adaptation to light. Aust. J. Biol. Sci. 26:295-307.

Epstein, E. 1972. Mineral nutrition of plants: Principles and perspective. John Wiley and Sons, New York.

Horst, G.L., C.J. Nelson, and K.H. Asay. 1978. Relationship of leaf elongation to forage yield of tall fescue genotypes. Crop Sci. 18:715-719.

Nelson, C.J., and K.H. Asay. 1974. Photosynthetic efficiency as a selection criterion in breeding forage grasses. Proc. Int. Grassl. Congr. 12th 1974:257-265.

-_-, - - , and G.L. Horst. 1975. Relationship of leaf photosynthesis to forage yield of tall fescue. Crop Sci. 15:476-478.

-_-, - -_, -_-, and E.S. Hilderbrand. 1974. Field measurements of photosynthesis in a forage grass breeding program. Crop Sci. 14:26-28.

-_- - - , and D.A. Sleper. 1977. Mechanism of canopy development in tall fescue genotypes. Crop Sci. 17:449-452.

---, and D.A. Sleper. 1983. Using leaf-area expansion rate to improve yield of tall fescue. Proc. Int. Grassl. Congr. 14th. 1983:413-416.

Ogren, W.L. 1976. Search for higher plants with modifications of the reductive pentose phosphate pathway of $\mathrm{CO}_{2}$ assimilation. p. 19-29. In R.H. Burris and C.C. Black (ed.) $\mathrm{CO}_{2}$ metabolism and plant productivity. University Park Press, Baltimore, MD.

Pallas, J.E., Jr., and Y.B. Samish. 1974. Photosynthetic response of peanut. Crop Sci. 14:478-482.

Pearce, R.B., G.E. Carlson, D.K. Barnes, R.H. Hart, and C.H. Hanson. 1969. Specific leaf weight and photosynthesis in alfalfa. Crop Sci. 9:423-426.

Sestak, Z., P.G. Jarvis, and J. Catsky. 1971. Criteria for the selection of suitable methods. p. 1-48. In Z. Sestak, P.G. Jarvis, and J. Catsky (ed.) Plant photosynthetic production manual of methods. W. Junk Publishing Co., The Hague.

Topark-Ngarm, Anake, I.T. Carlson, and R.B. Pearce. 1977. Direct and correlated responses to selection for specific leaf weight in reed canarygrass. Crop Sci. 17:765-769.

Treharne, K.J., and C.J. Nelson. 1975. Effect of growth temperature on photosynthetic and photorespiratory activity in tall fescue. p. 61-69. In R. Marcelle (ed.) Environmental and biological control of photosynthesis. W. Junk Publishing Co., The Hague.

Wilhelm, W.W., and C.J. Nelson. 1978a. Irradiance response of tall fescue genotypes with contrasting levels of photosynthesis and yield. Crop Sci. 18:405-408.

- - - and ---. 1978b. Leaf growth, leaf aging, and photosyn thetic rate of tall fescue genotypes. Crop Sci. 18:769-772.

Wilson, D., and J.P. Cooper. 1969. Apparent photosynthesis and leaf characteristics in relation to leaf position and age, among contrasting Lolium genotypes. New Phytol. 68:645-655.

Woledge, J. 1973. The photosynthesis of ryegrass leaves grown in a simulated sward. Ann. Appl. Biol. 73:229-237.

--, and O.R. Jewiss. 1969. The effect of temperature during growth on the subsequent rate of photosynthesis in leaves of tall fescue (Festuca arundinacea Schreb.). Ann. Bot. (London) 33:897913.

Zarrough, K.M., C.J. Nelson, and J.H. Coutts. 1983. Relationship between tillering and forage yield of tall fescue. I. Yield. Crop Sci. 23:333-337.

- - - - , and D.A. Sleper. 1984. Interrelationships between rates of leaf appearance and tillering in selected tall fescue populations. Crop Sci. 24:565-569. 